ISSN: 2162-3104 Print/ ISSN: 2166-3750 Online

Volume 8, Issue 3 (2018), pp. 1346-1354

(C) Journal of International Students

http://jistudents.org/

doi: 10.5281/zenodo. 1254592

\title{
Making Interactions Between Domestic and International Students Meaningful
}

\author{
Yukari Takimoto Amos \\ Central Washington University, USA \\ Nicole Rehorst \\ Central Washington University, USA
}

\begin{abstract}
The purpose of this practitioner narrative is to identify ways in which meaningful interaction can take place between English learners (ELs) and domestic students in a university setting. In order to learn English effectively, ELs require situations in which they can participate equally in an interaction with a domestic student capable of modifying their English so that it is comprehensible. We created a series of joint classes between teacher candidates and Japanese exchange students in an ESL class. In the class, the first author instructs the teacher candidates on strategies for teaching content to ELs. Second, the teacher candidates teach mini-lessons in their content area to Japanese students. The use of simplified English and visual aids allow ELs to gain confidence and the ability to participate more actively. Third, the Japanese students evaluate the teacher candidates in Japanese. Last, the first author translates the evaluations into English so the teacher candidates can gain meaningful feedback on their performance. The process effectively creates a balance of power that both educates teacher candidates in how to instruct nonnative English speakers and promotes meaningful communication and language growth in ELs. The conditions for meaningful interactions identified in this practice further contribute to the field of effective English learning for international students.
\end{abstract}

Keywords: English learners, meaningful interactions, Japanese international students, language barriers 
It is projected that by 2025, nearly one out of every four public school students will be English learners in the U.S. (National Clearinghouse for English Language Acquisition and Language Instruction Educational Programs, 2007). In 2014-15, the percentage of public school students who were ELs was 10.0 percent or more in the District of Columbia, Alaska, California, Colorado, Illinois, Nevada, New Mexico, and Texas (National Center for Educational Statistics, 2017). However, the population of teachers will likely remain predominantly white and native speakers of English. Furthermore, the majority of these teachers have never seriously experienced learning a language other than their own and most of them are largely untrained to work with ELs (Reeves, 2006). To produce teacher candidates who can effectively work with ELs, all teacher candidates in our university's teacher education program are required to take a class, EDBL 401: Principles and Practices for Educating English Language Learners. While teaching this class, the first author noticed that many teacher candidates have had zero to very little experience interacting with ELs before the class, and this situation undermined their understanding of ELs' academic and social needs.

Lucas and Grinberg (2008) assert that extended contact with nonnative speakers of English has a positive impact on teachers' attitudes towards ELs. To increase contact with ELs, the EDBL 401 class taught by the first author regularly collaborates with a university ESL program in the form of a joint class. In the joint class, teacher candidates teach a minilesson (15 to 20 minutes) based on their content areas in English to university ELs from Japan four times a quarter. For example, a math teacher candidate may teach a third-grade level math lesson, while a PE teacher candidate might teach a yoga lesson. Usually this mini-lesson is conducted in a small group setting where one teacher candidate carries two to three Japanese ELs. After each mini-lesson, the Japanese ELs evaluate the teacher candidates' teaching effectiveness using a rubric where they write comments in Japanese (see the appendix). The first author translates these comments into English and gives back the rubric to teacher candidates to reflect. These joint classes are immensely popular among both the teacher candidates and the Japanese ELs, because the interactions are both educational and meaningful. In this article, we reflect upon why the interactions become meaningful in a joint class from the Japanese ELs' perspectives. 


\section{LITERATURE REVIEW}

\section{INTERACTIONS BETWEEN DOMESTIC AND INTERNATIONAL STUDENTS}

Studies have consistently found that simply bringing domestic and international students together does not necessarily result in meaningful interactions (Leask, 2009; Osmond \& Roed, 2010). The most significant factor that influences interactions both positively and negatively is the language barrier. From domestic students' perspective, international students' lack of fluency in English affects the amount and the quality of interactions they have with the latter. When English proficiency is perceived to be inadequate, domestic students tend to conflate international students' language skills and intellectual ability (Ryan \& Viete, 2009; Trahar, 2007). In this mindset, language becomes a marker for an unspoken power relationship between the host students as "expert" and international students as "deficient" (Harrison \& Peacock, 2010). Due to the perceived accents and communication difficulties, Asian international students frequently receive comments from domestic students that presume that they are less intelligent (Kim \& Kim, 2010).

Several studies have exposed this power relationship and revealed that Asian international students sensed an assumption of unintelligence from their peers and professors because their accents were deemed unintelligible (Hsieh, 2007; Junious et al., 2010; Swagler \& Ellis, 2003). Moreover, Asian international students reported that they were ignored, devalued, and even discriminated against by domestic students. For example, Hanassab (2006) finds that many Asian international students felt that domestic students looked down on them, ignored them, and did not consider their opinions seriously.

Many international students themselves, particularly Asian students, seem to be aware of oral language barriers. They express feelings of inadequacy and frustration on their part while participating in oral classroom activities such as whole-class discussions and formal oral presentations in English (Kim, 2006; Liu, 2001; Morita, 2004). The higher the English proficiency is, the more meaningful interactions with domestic students may occur, and therefore the more intercultural learning takes place. For these reasons, studies, in general, conclude that spontaneous interactions between Asian international students and domestic students are rare (Li \& Campbell, 2008; Ward et al., 2005), and domestic students sometimes purposefully avoid the company of international students instead (Peacock \& Harrison, 2009). 


\section{THE CONDITIONS FOR MEANINGFUL INTERACTIONS}

There seem to be three main conditions for EL/domestic student interactions to become meaningful: self-perceptions, power relations, and monitoring. These conditions will be explained in this order.

\section{Self-Perceptions}

As the literature suggests, their inability to sufficiently and adequately use the English language may lead Japanese ELs to feel inferior to domestic students who are native speakers of English. This inferiority complex towards native English speakers is fueled by anxiety of speaking the language which they have not perfected, and this seems to prevent some Japanese ELs from engaging in conversations with domestic students. At the same time, most native speakers of English are not trained to interact with ELs. Therefore, they are not equipped with basic knowledge and techniques that are vital for interactions with ELs to be successful, such as slowing the speech speed, enunciating each word clearly, using simple vocabulary and grammar, and using visuals. The acquisition of the English language occurs when ELs are exposed to input that is linguistically comprehensible and is one step beyond their linguistic competence, which Krashen (1982) refers to as comprehensible input. Speaking slowly in simple vocabulary and grammar with visuals aids can lead to comprehensible input.

In a joint class, the Japanese ELs become the pupils of the teacher candidates and learn different content areas in English. The teacher candidates have learned how to make their lessons comprehensible to ELs in the EDBL 401 class and make an effort to demonstrate their knowledge with real ELs. They are taught to speak English slowly and in short sentences, proactively ask comprehension questions instead of waiting for the Japanese ELs to ask (which rarely happens), write down keywords on the board, use plenty of visuals (e.g., videos, photos, and pictures), and demonstrate rather than lecture.

Because the teacher candidates try to provide the Japanese ELs with comprehensible input, the latter have a much easier time understanding what the teacher candidates say and request in English. Considering that even international students who are relatively competent in English can find themselves understanding less than 10\% of lectures (Ryan \& Viete, 2009), the fact that the Japanese ELs comprehend the lesson conducted in English by a native English speaker carries a significant meaning to them. This experience seems to shift their mindset from deficient to competent ELs and boosts their self-esteem. Consequently, their raised self-esteem further encourages the Japanese ELs to participate more in the lesson verbally. The 
more this cycle is repeated, the better the participation rate and the higher the self-esteem on the part of the Japanese ELs.

\section{Power Relations}

In his contact theory, Allport (1954) stresses that in order for a successful interaction to take place between different groups, groups must have an equal status within the situation. When domestic and international students interact, domestic students typically dominate the conversation. They become the talker, while international students become the listener, thus the interaction is one-way. In order for interactions to be two-way, international students need to be listened to by domestic students.

In a joint class, the Japanese ELs are the pupils of the teacher candidates, but the former is also the latter's evaluator. After taking a minilesson from the teacher candidates, the Japanese ELs assess their counterparts' teaching effectiveness in various areas: speech, grammar, vocabulary, visual use, comprehension questions, and overall comprehensible input. Furthermore, they write detailed comments on the teacher candidates' strengths and weaknesses and make suggestions for improvement. These comments are written in Japanese, their native language, thus their assessments and critiques are not constrained by their insufficient English writing skills. While the Japanese ELs take time to write these comments, the teacher candidates patiently and anxiously wait for the assessment results. When the assessment results are returned to the teacher candidates a couple of days later, fully translated in English, they read the comments with pleasure and appreciation because the comments are useful for the betterment of their teaching skills.

The Japanese ELs assuming a role as an evaluator seems to effectively equalize the unequal power relations between them and the teacher candidates. In a joint class, the Japanese ELs' experiences as language learners, which have been juxtaposed with the teacher candidates' experiences as native speakers and labeled as deficient and inferior, transform themselves into valuable insights only ELs can have. In other words, the Japanese ELs become experts of the experiential-based pedagogical knowledge of ESL teaching. That is why the teacher candidates are eager to read the comments that the Japanese ELs make and appreciate their expert insights. Through the comments, the teacher candidates hear the Japanese ELs' voices and focused feedback. This situation rarely occurs in spontaneous and free interactions with domestic students. Therefore, it changes the existing power relations in contrast to typical situations where Japanese ELs are often silenced by domestic students. 


\section{Monitoring}

Allport's (1954) contact theory further dictates that interactions between groups must be sanctioned by authorities for them to be successful. Along with joint classes, we have paired the teacher candidates and the Japanese ELs as conversation partners and encouraged them to interact outside the class freely. However, we also hear from both the teacher candidates and the Japanese ELs that they have not taken advantage of the conversation partners program. The most frequently cited difficulty is arranging a time to meet, followed by language barriers. To some domestic students who have no interest in cross-cultural learning, interactions with international students, if they are not required, are something they would avoid.

A joint class is a part of the curriculum both for the teacher candidates and the Japanese ELs, and their participation is required to pass the class. Furthermore, the instructors of the class also play the role of counselor because they listen to both sides' concerns and suggestions and put them into practice accordingly. Although interactions occur primarily between the teacher candidates and Japanese ELs directly, both parties are aware that the instructors monitor their interactions and constantly advise both sides for betterment. It seems that this type of monitoring actually enhances the quality of interactions. We conduct joint classes only four times a quarter. However, the quality of interactions that the teacher candidates and the Japanese ELs collaboratively create appears to be more meaningful than more frequent free-style interactions in which domestic students tend to dominate in conversations with international students.

\section{CONCLUSIONS}

International students frequently perceive that domestic students and professors blame them for their unique patterns of participation (Archer, 2007), as well as language difficulties, and this perception implies that the solution lies solely with international students (Sawir, 2005). Our successful implementation of joint classes suggests, however, that it is both domestic and international students that need to make an effort for their interactions to be meaningful. Domestic students should be mindful of making themselves comprehensible by nonnative-speaking international students. If they speak and behave as they normally do, they will dominate the interactions, thus meaningful interactions will not occur. In addition, a carefully-monitored learning environment where nonnative-speaking international students and domestic students become equal in status should be pursued. If these steps are not taken proactively, even frequent interactions will be meaningless. 


\section{REFERENCES}

Allport, G. (1954). The nature of prejudice (25 th anniversary ed). New York: Basic Books.

Archer, L. (2007). Diversity, equality and higher education: A critical reflection on the abuses of equity discourse within widening participation. Teaching in Higher Education, 12(5-6), 635-653.

Hanasaab, S. (2006). Diversity, international students, and perceived discrimination: Implications for educators and counselors. Journal of Studies in International Education, 10(2), 157-172.

Hseieh, M. (2007). Challenges for international students in higher education: One student's narrated story of invisibility and struggle. College Student Journal, 41(2), 379-391.

Junious, D.L., Malecha, A., Tart, K., \& Young, A. (2010). Stress and perceived faculty support among foreign-born baccalaureate nursing students. Journal of Nursing Education, 49(5), 261-270.

Kim, S. (2006). Academic oral communication needs of East Asian international graduate students in non-science and non-engineering fields. English for Specific Purposes, 25(4), 479-489.

Krashen, S. (1982). Principles and practice in second language acquisition. Oxford, UK: Pergamon.

Leask, B. (2009). Using formal and informal curricula to improve interactions between home and international students. Journal of Studies in International Education, 13(2), 205-221.

Li, M., \& Campbell, J. (2008). Asian studets' perceptions of group work and group assignments in a New Zealand tertiary institution. Intercultural Education, 19(3), 203-216.

Liu, J. (2001). Asian students' classroom communication patterns in U.S. universities: An emic perspective. Westport, CT: Ablex.

Lucas, T., \& Grinberg, J. (2008). Responding to the linguistic reality of mainstream classes: Preparing all teachers to teach English language learners. In M. Cochran-Smith, S. Feiman-Nemser, D.J. McIntyre, \& K.E. Demers (Eds.), Handbook of research on teacher education: Enduring questions in changing contexts ( $3^{\text {rd }}$ ed.) (pp. 606-636). New York: Routledge.

Morita, N. (2004). Negotiating participation and identity in second language academic communities. TESOL Quarterly, 38(4), 573-604.

National Center for Education Statistics. (2017). The condition of education 2017: English language learners in public schools. Retrieved from https://nces.ed.gov/programs/coe/indicator_cgf.asp

National Education Association. (2007). An NEA policy brief: English language learners face unique challenges. Retrieved from: http://www.nea.org/assets/docs/HE/ELL_Policy_Brief_Fall_08_\%282\%29.pdf

Osmond, J, \& Roed, J. (2010). Sometimes it means more work...: Student perceptions of group work in a mixed cultural setting. In E. Jones (Ed.), Internationalisation and the student voice: Higher education perspectives ( $\mathrm{pp}$. 113-124). New York: Routledge.

Peacock, N., \& Harrison, N. (2009). "It's so much easier to go with what's easy": "Mindfulness" and the discourse between home and international students in 
the United Kingdom. Journal of Studies in International Education, 13(4), 487-508.

Reeves, J. (2006). Secondary teacher attitudes toward including English-language learners in mainstream classes. Journal of Educational Research, 99(3), 131143.

Ryan, J., \& Viete, R. (2009). Respectful interactions: Learning with international students in the English-speaking academy. Teaching in Higher Education, 14(3), 303-314.

Sawir, E. (2005). Language difficulties of international students in Australia: The effects of prior learning experience. International Education Journal, 6(5), 567-80.

Swagler, M.A., \& Ellis, M.V. (2003). Crossing the distance: Adjustment of Taiwanese graduate students in the United States. Journal of Studies in International Education, 13(2), 72-109.

Trahar, S. (2007). Teaching and learning: The international higher education landscape-some theories and working practices. Retrieved from: http://escalate.ac.uk/3559

Ward, C., Masgoret, A-M., Ho, E., Holmes, P., Newton, J., \& Crabbe, D. (2005). Interactions with international students: Report prepared for education New Zealand. Center for Applied Cross-Cultural Research, Victoria University of Wellington.

\section{APPENDIX}

\section{Rubric for Teaching Demo（指導評価表）}

Student's Name

\begin{tabular}{|l|l|l|l|}
\hline & $\begin{array}{c}\text { Exceed } \\
\text { standards } \\
\text { 良 }\end{array}$ & $\begin{array}{c}\text { Meet } \\
\text { standards } \\
\text { 可 }\end{array}$ & $\begin{array}{c}\text { Need } \\
\text { improvement } \\
\text { 不可 }\end{array}$ \\
\hline $\begin{array}{l}\text { Appropriate speed } \\
\text { 早くやべっていない。 }\end{array}$ & & \\
\hline $\begin{array}{l}\text { Simplified grammar } \\
\text { 簡な単な法を使っている。 }\end{array}$ & & \\
\hline $\begin{array}{l}\text { Use of familiarwords } \\
\text { 難しい単語を使っていな } \\
\text { い。 }\end{array}$ & & & \\
\hline $\begin{array}{l}\text { Use of gestures } \\
\text { ジェスチャーがあるので分 } \\
\text { りやすい。 }\end{array}$ & & & \\
\hline $\begin{array}{l}\text { Clear directions } \\
\text { 何をしていいのか分りやす } \\
\text { く説明してくれる。 }\end{array}$ & & & \\
\hline $\begin{array}{l}\text { Comprehension check } \\
\text { 内容を本当に分かっている } \\
\text { か、頻繁に確認してくれ }\end{array}$ & & & \\
\hline
\end{tabular}




\begin{tabular}{|l|c|c|c|}
\hline & $\begin{array}{c}\text { Exceed } \\
\text { standards } \\
\text { 良 }\end{array}$ & $\begin{array}{c}\text { Meet } \\
\text { standards } \\
\text { 可 }\end{array}$ & $\begin{array}{c}\text { Need } \\
\text { improvement } \\
\text { 不可 }\end{array}$ \\
\hline る。 & & & \\
\hline $\begin{array}{l}\text { Teaching content areas } \\
\text { 教科の内容がよく分かる。 }\end{array}$ & & & \\
\hline $\begin{array}{l}\text { Use of visuals } \\
\text { 絵や写真などをたくさん使 } \\
\text { つている。 }\end{array}$ & & & \\
\hline
\end{tabular}

Good teaching points （ここが良かったという点を書いて下さい）

Points to improve（もう少しこうしたら良くなるという点いて下さい）

YUKARI TAKIMOTO AMOS, PhD, is a professor in the Department of Education, Development, Teaching and Learning at Central Washington University where she teaches multicultural education and TESL-related classes. Her research interests include teachers of color's experiences, studies of immigrant students' English language learning, international students at American universities, studies of Japanese as a second language among immigrants in Japan, and the dispositions of pre-service teachers towards cultural and linguistic diversity. Email: cjbyukari@hotmail.com

NICOLE REHORST, MA, is an instructor of English in the Asia University America Program at Central Washington University. Her research interests include the international influence on culture and society in Meiji era Japan. Email: nrehorst@cwu.edu 